\title{
DROMOLOGI DAN ERA FLASH SALE: TINJAUAN GELIAT MANUSIA DALAM CYBERSPACE
}

\author{
Bagus Ardiyansyah, Drajat Tri Kartono, dan Argyo Demartoto \\ Program Studi Magister Sosiologi, Fakultas Ilmu Sosial dan Ilmu Politik, \\ Universitas Sebelas Maret, Surakarta \\ bagusa581@gmail.com
}

\begin{abstract}
The rate of development of information and communication technology today is increasingly massive and almost every time gives birth to new. Consumer activity has also shifted to the digital sector, or more massive in the artificial sector than in the real world. This is an era that is influenced by digital-economy, namely posekonomi. With its advantages, space-time freezing and freezing occur or in short space-time efficiency. The output of a human being created as a thinker, which uses his passion through the use of digital literacy in economic lines. One marketplace for buying daily necessities that is often visited by real people is Shopee. For the sake of maintaining the existence in the minds of consumers, Shopee began to aggressively take actions to link consumers or the community, one of them by making a flash sale. Furthermore, through descriptive-explanative qualitatif methods with the type of library research; praxis loading and freezing of space-time (dromology) that happened as described by Paul Virilio in digital development, as a responsive substitution of real economic activity into the digital economy. Shopee uses strategic reality, the power of knowledge and the power of movement, even to make the body a commodity repretoire.
\end{abstract}

Keywords: dromology, digital economy, Shopee, and flash sale

\begin{abstract}
Abstrak
Laju perkembangan teknologi informasi dan komunikasi dewasa ini semakin masif serta nyaris setiap waktunya melahirkan hal-ihwal yang baru. Aktivitas konsumerisme atau belanja pun telah beralih pada sektor digital, atau lebih masif pada sektor artifisial daripada di dunia
\end{abstract}


nyata. Inilah suatu era yang dipengaruhi oleh digital-ekonomi, yakni posekonomi. Dengan keuntungannya, terjadi pemampatan dan pembekuan ruang-waktu atau singkatnya efisiensi ruang-waktu. Salah satu marketplace untuk membeli kebutuhan sehari-hari yang sering dikunjungi oleh masyarakat nyata adalah Shopee. Demi menjaga eksistensi dalam pikiran konsumennya, Shopee mulai gencar melakukan aksi-aksi untuk mengkait para konsumen atau masyarakat, salah satunya dengan membuat flash sale. Lebih jauh, melalui metode kualitatif deskriptif-eksplanatif dengan jenis penelitian kepustakaan; praksis pemampatan dan pembekuan ruang-waktu (dromologi) yang terjadi itulah sebagaimana yang digambarkan oleh Paul Virilio dalam perkembangan digital, sebagai responsif substitusi dari aktivitas ekonomi rill ke ekonomi digital. Shopee menggunakan realitas strategis, kekuasaan pengetahuan, dan kekuasaan pergerakan, bahkan hingga menjadikan tubuh sebagai repertoire komoditi.

Kata Kunci: dromologi, ekonomi digital, Shopee, dan flash sale

\section{PENDAHULUAN}

Fenomena modernisasi terjadi di segala sendi kehidupan, termasuk dalam bidang ekonomi, dengan munculnya pasar digital selain pasar tradisional dan pasar modern (Piliang, 2009: 81). Perkembangan laju ekonomi ini mempunyai konsekuensi bagi para pelaku usaha di dalamnya. Di sisi lain, fenomena terkait merupakan gambaran dari kemampuan sumber daya manusia dalam kecakapan teknologi digital pada konteks usaha, yakni melahirkan rumus baru "literasi digital + ekonomi $=$ pasar digital (realitas kedua)". Secara umum, pasar merupakan ranah atau medium terjadinya proses jual-beli, interaksi antara penjual dan pembeli, juga sebagai ranah perantara dalam pemenuhan kebutuhan kehidupan.

Berdialek ihwal pasar, maka pasar dikategorikan menjadi dua jenis, yakni pasar tradisional dan pasar modern (Ariyani dan Nurcahyono, 2014), tetapi kini telah muncul jenis pasar yang ketiga, yakni pasar digital. Pertama, pasar tradisional ialah ranah pertemuan atau interaksi antara penjual dan pembeli yang terjadi secara langsung (bertatapan secara langsung tanpa perantara). Kedua, pasar modern merupakan ranah sistem transaksi yang terjadi secara tidak langsung, pelayanan bersifat mandiri, harga barang tidak bisa di tawar, bertatapan secara langsung terjadi saat akan membayar, yang bisa dilakukan secara tunai ataupun nontunai. Ketiga, pasar digital ialah akibat dari hipercepat kemajuan pengaruh teknologi dan komunikasi, yaitu internet, yang merupakan gabungan dari pasar tradisional dan modern, yakni di dalam proses transaksinya ada yang bisa terjadi proses tawar-menawar, pembayaran dilakukan secara non-tunai atau nirkertas (via transfer), interaksi terjadi dengan perantara gadget, dan menghemat energi tanpa harus datang ke tempat penjual (baca: melipat jarak, ruang, dan waktu).

Fenomena ekonomi dengan kemunculan pasar digital tersebut dipengaruhi oleh perkembangan spatkapitalisme (produksi kebutuhan semu) (Osborne dan Van Loon, 1998: 43; 
Damsar dan Indrayani, 2015: 17). Laju perkembangan spat-kapitalisme, budaya pascamodern, dan teknologi cyberspace hingga dewasa ini telah membawa masyarakat ke dalam beragam arus perubahan yang hipercepat. Arus perubahan hipercepat ini, ibaratnya adalah dunia yang terus berlari; tidak pernah mengurangi tempo produksi, konsumsi, dan kecepatan informasinya, sehingga membuat atau mengondisikan manusia tak bisa beristirahat sedikit pun (Piliang, 2017: 42). Salah satu contoh produk dari dunia yang tak pernah berhenti berlari ini adalah internet.

Melalui kemajuan informasi dan teknologi ini, manusia menjelma bahkan menandingi Tuhan dengan menguasai ruang, menguasai jarak, menguasai waktu, dan menciptakan tubuh virtual. Artinya, kini manusia seolah mempunyai kekuasaan atau kekuatan tak terbatas seperti Tuhan (Piliang, 2017: 28). Inilah citra penampakan spirit kapitalisme di dalam spirit pascamodernisme dan di dalam spirit cyberspace, sebuah dunia yang dikuasai oleh informasi atau penampakan digital.

Penetrasi dari angka pengguna internet tersebut ibarat tambang emas bagi aktor yang akan terjun ke e-commerce (pasar digital). Laju percepatan kenaikan pengguna internet ini, berimbas sampai ke ranah transaksi jual-beli, di mana masyarakat lebih memilih melakukan pembelian tidak lagi lewat pasar nyata, tetapi lewat pasar digital. Perubahan lanskap kehidupan sosial di era inovasi teknologi komputer dan komunikasi yang meningkatkan kemampuan manusia dalam memproduksi, mendistribusikan, dan mengonsumsi informasi secara masif lewat beragam media (Yanti dan
Yusnaini, 2018). Inilah yang akhirnya menyebabkan menjamurnya toko-toko online yang ada di Indonesia, seperti Shopee, Lazada, Tokopedia, Blibli.com, Zalora, Bukalapak, dan lain sebagainya. Hal ini karena masyarakat lebih banyak menghabiskan waktunya untuk berselancar di internet, termasuk dalam bertransaksi online. Suatu gambaran terwujudnya apa yang diinginkan oleh pemerintah, yang mencanangkan Indonesia sebagai largest digital economy pada 2020 dan menargetkan menjadi yang terbesar di Asia Tenggara.

\section{TABEL 1. Daftar toko online dan durasi waktu kunjungan}

\begin{tabular}{|l|l|}
\hline \multicolumn{1}{|c|}{$\begin{array}{c}\text { Toko Belanja } \\
\text { Online }\end{array}$} & \multicolumn{1}{c|}{$\begin{array}{c}\text { Kata-rata Waktu } \\
\text { Kungan }\end{array}$} \\
\hline Shopee & 9 menit: 34 detik \\
\hline Mapemall & 9 menit: 02 detik \\
\hline Berrybenka & 6 menit: 39 detik \\
\hline Tokopedia & 5 menit: 54 detik \\
\hline Zalora & 5 menit: 49 detik \\
\hline Bukalapak & 5 menit: 32 detik \\
\hline Bro.do & 5 menit: 30 detik \\
\hline Lazada & 5 menit: 15 detik \\
\hline VIP Plaza & 4 menit: 30 detik \\
\hline Hijup & 4 menit: 29 detik \\
\hline Sale Stock ID & 4 menit: 27 detik \\
\hline Weshop & 4 menit: 19 detik \\
\hline Blanja & 4 menit: 07 detik \\
\hline Sociolla & 4 menit: 06 detik \\
\hline Tees.co.id & 3 menit: 54 detik \\
\hline Hijabenka & 3 menit: 40 detik \\
\hline Jd.id & 3 menit: 37 detik \\
\hline Bhinneka & 3 menit: 15 detik \\
\hline
\end{tabular}




\begin{tabular}{|l|l|}
\hline \multicolumn{1}{|c|}{$\begin{array}{c}\text { Toko Belanja } \\
\text { Online }\end{array}$} & \multicolumn{1}{|c|}{$\begin{array}{c}\text { Rata-rata Waktu } \\
\text { Kunjungan }\end{array}$} \\
\hline Bobobobo & 3 menit: 10 detik \\
\hline Qoo10 & 2 menit: 56 detik \\
\hline AliExpress & 2 menit: 43 detik \\
\hline Blibli & 2 menit: 36 detik \\
\hline Otten Coffee & 2 menit: 27 detik \\
\hline Elevenia & 2 menit: 15 detik \\
\hline
\end{tabular}

(Sumber: iPrice, 2018)

Tabel di atas (lihat Tabel 1), memperlihatkan rata-rata semua toko online di Indonesia memiliki time on site (waktu kunjungan) yang baik. Oleh karena, menurut search engine Bing, ratarata waktu kunjungan website dianggap baik apabila pengguna menghabiskan waktunya paling tidak semenit atau dua menit, bahkan jika waktu kunjungannya lebih dua menit menunjukkan sangat baik (iPrice, 2018). Semua itu juga dipengaruhi oleh kelengkapan konten serta tampilan yang menarik, sehingga menggoda masyarakat atau pengguna nyaman berbelanja dan betah berlamalama di website tersebut. Sementara itu, fenomena percepatan ini dan aksi aktor yang lebih mengonsumsi di dunia virtual atau pasar digital mengakibatkan semakin tergurusnya ritel-ritel atau tokotoko offline yang sudah ada sebelum kemunculan toko online.

Inilah realitas yang dihadapi pada abad ke-21; suatu dunia dengan laju lalulintas informasi yang masif dan akan menghancurkan apa serta siapa saja yang tidak siap menerima laju percepatannya. Lebih jauh, salah satu aplikasi marketplace dewasa ini yang sedang marak digunakan oleh konsumen atau masyarakat adalah Shopee. Shopee merupakan aplikasi marketplace online yang diperuntukkan proses jual-beli di ponsel dengan mudah dan cepat, juga mengusung konsep C2C (konsumen ke konsumen). Aplikasi ini, merupakan anak perusahaan dari Garena yang sekarang berganti nama menjadi SEA Group yang berbasis di Singapura, mulai masuk ke pasar Indonesia pada akhir bulan Mei 2015 dan beroperasi pada akhir Juni 2015 di Indonesia (Jeko, 2015). Di dalam aplikasinya, Shopee menawarkan beragam produk, sampai dengan produk kebutuhan seharihari dengan harga yang terjangkau dan setiap barangnya mempunyai diskon atau potongan harga. Dengan menggunakan aplikasi mobile, semakin memudahkan pengguna atau konsumen dalam penggunaan kegiatan berbelanja tanpa harus membuka website-nya lewat perangkat komputer atau laptop. Dengan kata lain, ini sebagai perwujudan dari fenomena percepatan waktu atau pemadatan waktu, yang disebut Paul Virilio dengan istilah dromologi.

Selain itu, aplikasi ritel online ini juga memberikan layanan gratis ongkos kirim (gratis ongkir) ke seluruh Indonesia, yang membuat semakin 'histeria' konsumen atau masyarakat menggunakan aplikasi ini dalam berbelanja. Shopee juga menampilkan interface dengan fungsi chatting di dalam aplikasi, sehingga penjual atau pembeli bisa berbelanja dan berkomunikasi secara real time yang menambah kenyamanan dalam penggunaan aplikasi ini (Putri, 2015). Dalam aplikasi Shopee, pembeli bisa melakukan proses tawar-menawar, seperti pada pasar konvensional melalui fitur tawar yang disediakan. Lebih jauh, jika ditelisik dengan seksama, inilah representasi atau citra kehidupan 
kontemporer, yakni pengurangan jarak melalui pemadatan waktu menjadi realitas keseharian manusia kontemporer, kegemaran efisiensi atau memanipulasi segalanya.

Lebih jauh, beberapa waktu lalu Shopee memberikan penawaran harga atau diskon yang tergolong sangat 'gila' bagi konsumennya, yakni serba-serbi 9.9 Super Flash Sale Shopping Day yang berlangsung dari tanggal 27 Agustus sampai 09 September 2018. Di lihat dari fenomena ini adalah salah satu wujud dari konsep Virilio yang disebut dromologi, yakni tentang percepatan waktu.

Selanjutnya, prinsip sentral atau pusat dalam ekonomi kapitalisme global ialah kecepatan dan percepatan. Artinya, segala sesuatu berubah, bergerak, dan bertransformasi dalam waktu yang singkat. Segalanya muncul dalam keseketikaan, juga menghilang dengan waktu yang sama. Fenomena ini merepresentasikan dunia 'keseketikaan' atau 'kesegeraan' - terwujud dari promo Flash Sale 9.9 dari Shopee - yang segalanya muncul serta menghilang secara instan. Bagi kapitalisme global, menaklukan ruang serta waktu adalah hal yang penting, karena penaklukan tersebut demi meringkas jarak serta ruang (prinsip instanisasi) (Piliang, 2017: 32). Menilik penjelasan di atas, maka analisis dalam penelitian ini untuk menjabarkan bagaimana dromologi ekonomi digital dan era flash sale yang tercitrakan dalam aplikasi toko online Shopee di Indonesia.

\section{KERANGKA TEORI}

"Dromology" berasal bahasa dari Yunani dromos, berarti race atau racecourse. Dromologi, kemudian, adalah sebuah tubuh pengetahuan yang bersangkutan secara khusus dengan fenomena kecepatan, atau lebih tepatnya, dengan cara bagaimana kecepatan menentukan atau membatasi cara di mana fenomena muncul kepada kita. Paul Virilio adalah seorang teoritisi Perancis yang menciptakan suatu bentuk kajian yang inovatif dan membangkitkan minat yang pantas mendapat pengakuan luas. Kajiannya mengenai dromologi berasal dari akhiran "drome" yang merujuk pada jalur lomba lari atau tempat balapan mobil; dalam kajiannya, Virilio (1991a: 91) mengindikasikan minat utamanya pada "pentingnya kecepatan yang menentukan".

Pada tingkat yang lebih luas, Virilio tertarik mengenai hancurnya batas-batas yang disebabkan oleh perubahan teknologi yang kelewat dalam bentuk transportasi, komunikasi, telekomunikasi, komputerisasi, dan seterusnya. Bentuk awal perubahan ini menyebabkan perubahan atas susunan yang spasial, "distingsi di sini dan di sana tak lagi berarti apa-apa." Dengan kata lain, saat sekarang hal ini menimbulkan sedikit atau tidak ada perbedaan apakah seseorang tinggal di kota, pinggiran, atau daerah pedesaan. Sama halnya, apakah seseorang tinggal di Amerika Serikat, Inggris atau Jepang, bahkan Indonesia.

Lebih jauh, kebanyakan Virilio lebih tertarik dengan persoalan waktu daripada runag, karena waktu lebih penting daripada ruang di dunia postmodern. Kenyataannya dia menguraikan meningkatnya kecepatan menyebabkan terkikisnya distingsi parsial dan sangat sulit membedakan ruang dan waktu. Walhasil, pembuluh sinar Katoda, apakah ia dijumpai dalam televisi kita atau bersemayam dalam 
komputer kita, "dimensi spasial menjadi tidak dapat dipisahkan dari kecepatan transmisi" (Virilio, 1991a: 14). Dalam arti lain, ruang dan waktu makin tidak dapat dibedakan dari yang lain. Lebih jauh, kecepatan membanjiri jarak; "akselerasi dan pengurangan kecepatan, atau pergerakan dari pergerakan, ruangdromospherik" (Virilio, 1991a: 102). Jadi, Virilio (1991a: 18) menciptakan prinsip "jarak kecepatan" dan menjelaskan bahwa ia menghancurkan fisik dan dimensi spasial. Saat ini yang paling penting adalah majunya sarana komunikasi dan telekomunikasi. Apa yang dihadapi masyarakat zaman modern ini merupakan sebuah krisis konseptualisasi dan representasi. Kecepatan dan cara dimana peningkatan kecepatan transmisi membentuk persepsi individu, tidak hanya kehidupan sosial, namun juga politik dan budaya. Kecepatan membuat manusia untuk terus bergerak atau memaksa untuk tidak diam, meskipun kita didalam pesawat kita terus bergerak. Kemajuan teknologi, baik di bidang transportasi, komunikasi, dan apa pun itu membuat manusia menghabiskan lebih banyak waktu dalam posisi inert atau stasioner.

Dalam mempermudah pemahaman kita mengenai teori dromologi ini, bisa kita lihat pada seseorang yang berwisata atau berpergian mengendarai suatu kendaraan, di mana keadaan tanah di depan seakan keadaannya lebih tinggi dari wisatawan tersebut, dan pemandangan yang berada di depan mobil akan terlihat bergantian sesuai giliran waktu yang paling terdekat, dari kejauhan seakan animasi yang sudah pasti akan dihadapi. Segala sesuatu yang dilewati seakan datang dengan cepat dan tiba-tiba. Di sini berarti manusia dihadapkan pada situasi yang selalu bergerak (percepatan), sehingga manusia diharuskan untuk selalu bergerak dan mengikuti perkembangan yang ada, karena bila dilihat dari contoh di atas lagi, sesuatu yang terlewati begitu cepat, dan sesuatu yang datang tiba-tiba akan cepat hilang. Oleh karena itu, manusia tidak boleh diam agar tidak ketinggalan mendapatkan hal-hal baru yang cepat hilang. Teori percepatan ini membuat waktu seakan menembus semua batas kehidupan yang apabila waktu berhenti, maka kehidupan juga ikut berhenti. Lebih dalam, untuk mempermudah lagi pemahaman ini, yakni pada analisis terkait pembahasan dalam penelitian ini.

\section{III.METODE}

Penelitian ini menggunakan metode penelitian kualitatif yang bersifat deskriptif-eksplanatif untuk menjelaskan dan menganalisis dromologi dan era flash sale. Lebih jauh, metode deskriptifeksplanatif sebagai metode yang dapat digunakan untuk meneliti sekelompok manusia, suatu kondisi, suatu sistem pemikiran ataupun suatu kelas peristiwa pada masa sekarang. Oleh sebab itu, jenis penelitian dalam pengkajian ini adalah kepustakaan (library research), pada berbagai bahan tertulis yang relevan dengan penelitian ini (Manulang, 2004: 35). Selanjutnya, sumber data primer pun terkait dengan Shopee, baik lewat situs atau aplikasinya dan lainnya yang relevan. Di sisi lain, data sekundernya adalah data pendukung yang relevan dengan penelitianini, sepertijurnal, buku, laporan atau berita, dan lain sebagainya (Furchan dan Maimun, 2005: 54). Analisis dalam penelitian ini dilakukan guna menggali 
dan menunjukkan terkait dromologi dan era flash sale Shopee. Tahap pertama dalam analisis data dimulai dengan mengumpulkan kepustakaan sebagaimana yang telah dipaparkan dalam metode pengumpulan data. Cara terkait memberikan kesempatan untuk memperoleh data baru sekaligus mengoreksi data tersebut. Pada tahap berikutnya dilakukan analisis lebih dalam atau penilaian atas data yang telah ada dan terkumpul. Sehubungan dengan hal tersebut, beragam data yang relevan digunakan dalam penelitian dengan berpegang pada prinsip validitas, realibilitas, dan otentitas. Setelah tahapan tersebut dilakukan, maka tahapan selanjutnya adalah interpretasi data (Bakker dan Zubair, 1990: 54).

\section{HASIL DAN \\ PEMBAHASAN}

\subsection{Latar Belakang Shopee}

Shopee merupakan

salah

satu perusahaan e-commerce yang memungkinkan para penggunanya membeli atau menjual barang melalui aplikasi yang tersedia di platform iOS dan Android. Shopee didirikan oleh seorang pria lulusan terbaik dari Universitas Nasional Singapura bernama Chris Feng. Shopee menjadi salah satu marketplace online yang menawarkan kemudahan berbelanja berbagai macam produk, seperti pakaian, peralatan elektronik, peralatan rumah tangga, sepatu, tas, makanan, dan berbagai jenis produk lainnya (lihat Gambar 2).

Shopee pertama kali diperkenalkan di Singapura, kemudian disusul Malaysia, Filipina, Taiwan, Thailand, Vietnam, dan Indonesia. Visi yang diusung Shopee

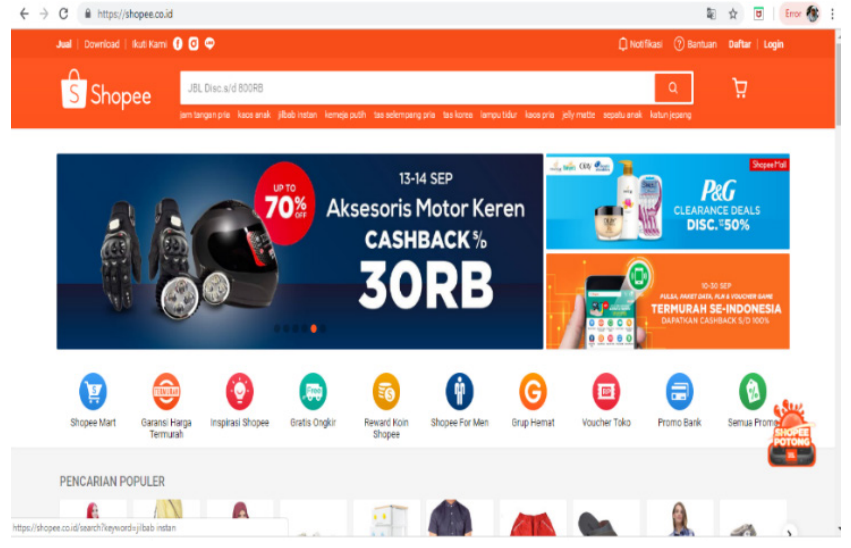

(Sumber: www.Shopee.co.id/)

Gambar 2. Tampilan Shopee

adalah "Menjadi Mobile Marketplace Nomor 1 di Asia Tenggara". Shopee mulai masuk dan diresmikan di Indonesia secara resmi pada Desember 2015 di bawah naungan PT. Shopee International Indonesia (Jeko, 2015). Shopee Indonesia mendapatkan dukungan finansial penuh dari SEA Group. Pada saat peluncuran Shopee di Indonesia mendapatkan dana dari SEA dan beberapa modal ventura, seperti Farallon Capital Management, Hillhouse Capital, GDP Venture, JG Summit Holdings Inc untuk melakukan penetrasi pada online market di Indonesia. Dukungan penuh ini yang pada akhirnya membuat Shopee berkembang cukup pesat di Indonesia.

Potensi yang masif dari konsumen terhadap online shop membuat perkembangan Shopee cukup pesat di Indonesia. Hal ini terbukti dengan sebesar 18 juta dari 50 juta pengguna Shopee berasal dari Indonesia. Lebih dari itu, total chat yang dilakukan di Shopee pada tahun 2016 lebih dari 120 juta kali. Bahkan, hingga Oktober 2017 aplikasi Shopee sudah didownload lebih dari 43 juta pengguna. Hal ini membuktikan bahwa antusias masyarakat terhadap 
Shopee cukup besar. Fenomena ini kiranya yang menggambarkan manusia (di)genggam teknologi.

Kesuksesan Shopee tidak terlepas dari strategi pemasaran yang dilakukan. Shopee menyediakan berbagai sistem pembayaran yang mudah dan efisien melalui transfer bank, Indomaret, Kredivo, hingga kartu kredit. Selain itu, tersedia juga dompet elektronik "Shopee Pay" yang dapat menyimpan seluruh dana, baik dari penjualan atau pembelian. Shopee Indonesia juga memiliki fitur "Koin Shopee", yaitu koin virtual yang diperoleh dari hasil pembelian barang dengan promo tertentu dengan sistem cashback. Nantinya, "Koin Shopee" ini dapat ditukar dengan diskon saat pembelian barang berikutnya. Strategi ini membuat ketertarikan bagi konsumen untuk kembali mengakses dan membeli barang yang ada di Shopee (Yolania, 2016). Selain itu, strategi keamanan juga diberikan Shopee untuk memperoleh kepercayaan konsumen. Dalam memastikan barang yang dikirim penjual sampai ke pembeli, Shopee Indonesia memberlakukan sistem "Garansi Shopee" sebagai jaminan uang akan kembali $100 \%$ jika barang tidak sampai. Semakin membuat masyarakat tidak lagi ragu atau khawatir terhadap kemungkinan terjadinya penipuan dalam transaksi jual-beli.

Pemberian berbagai promo dan diskon juga menjadi daya tarik Shopee terhadap masyarakat. Beberapa promo tersebut diantaranya gratis ongkir, cash back, voucher belanja, dan flash sale (Nugroho, 2016). Gratis ongkir adalah pembebasan biaya pengiriman dari penjual terhadap pembeli yang biasanya biaya ini dibebankan kepada pembeli. Sementara itu, cashback adalah pengembalian sejumlah uang kepada pembeli yang telah membeli salah satu produk bertanda khusus. Shopee juga memberikan voucher belanja, yakni pemberian kode khusus yang dapat digunakan pembeli untuk memperoleh pemotongan harga barang. Lebih jauh, Shopee juga memanfaatkan strategi flash sale untuk menarik minat pembeli. Flash sale adalah pemberian harga khusus yang bercirikan angka 9. Barang yang dijual dimulai dari harga Rp. 9,- untuk berbagai jenis barang khusus. Berbagai strategi ini terbukti mampu menarik minat masyarakat. Hal tersebut dibuktikan dengan lebih dari tiga juta produk terjual dalam salah satu promo Flash Sale Shopee (seperti ditunjukkan Gambar 3).

\subsection{Praktik Dromologi dan Era Flash Sale Shopee}

Dromologi merupakan istilah untuk menjelaskan keadaan atau ilmu tentang kecepatan dalam berbagai fenomena kehidupan. Berkembanganya dromologi menjadi suatu identitas kebudayaan baru tak bisa dihindarkan telah melahirkan beragam aspek kehidupan dalam masyarakat, misalnya saja interaksi sosial berjalan tidak secara normatif, tapi termediasi oleh media akibat perkembangan teknologi, meleburkan ruang dan waktu. Efek kecepatan dan percepatan juga memengaruhi aktivitas ekonomi. Hal ini terlihat dalam perubahan aktivitas pertukaran, transaksi, dan alat tukar ekonomi (uang), yang menciptakan semacam "ekonomi digital". Salah satu contohnya adalah lahirnya pasar digital (marketplace), yakni online shop, dan dalam pembahasan ini adalah Shopee. 
12:06

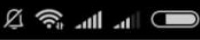
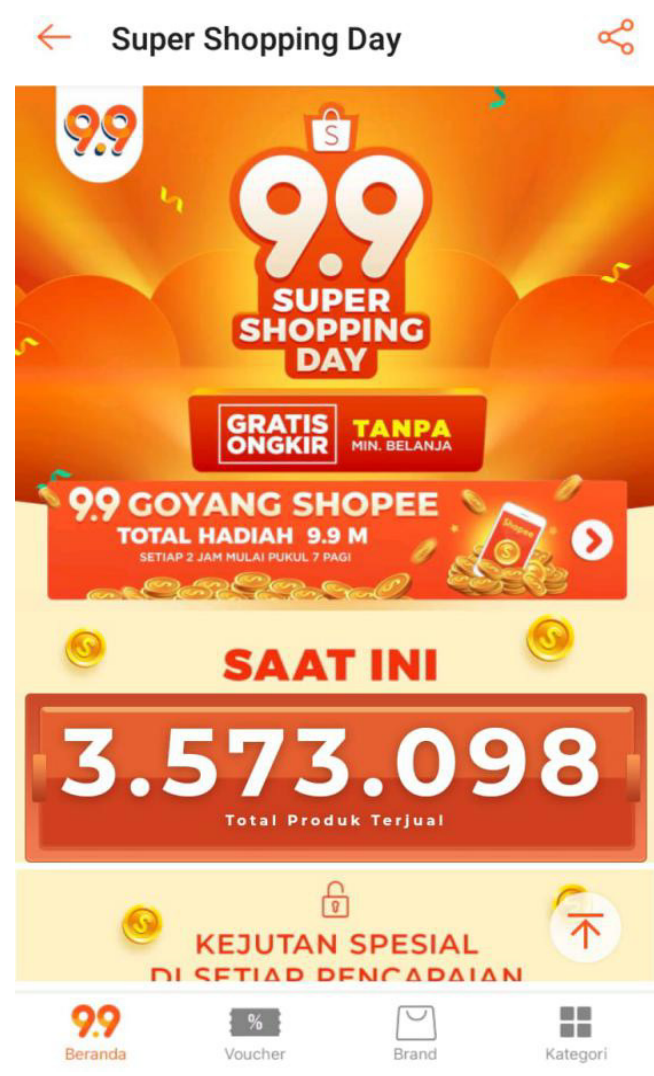

$11: 58$

$\leftarrow$ F4ASH SALE
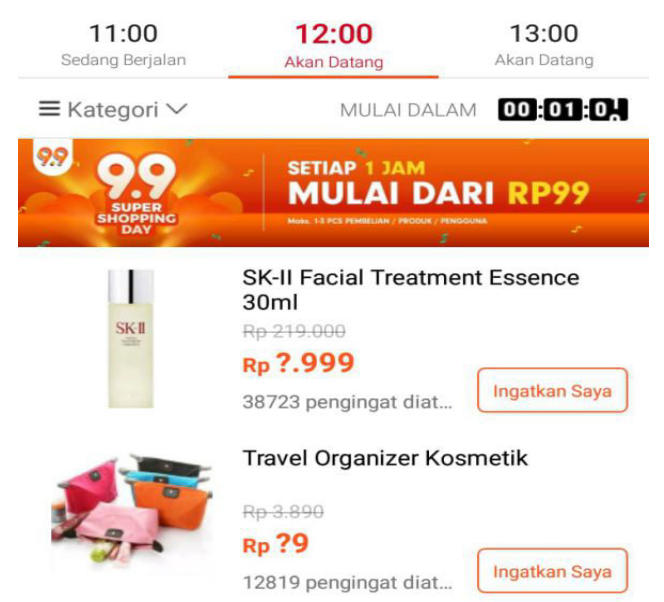

Mamonde Water Rose Toner $25 \mathrm{ml}$

ENap 30.000

Rp ?9

13459 pengingat diatur Ingatkan Saya

Spons Beauty Blender

(Sumber: www.Shopee.co.id/)

Gambar 5. Strategi bisnis Shopee dalam bentuk Flash Sale
Shopee yang memungkinkan dan memudahkan proses jual-beli antar penjual-pembeli yang jaraknya terpisah oleh garis horizon (jauh), lewat aplikasi ini, jarak, ruang, dan waktu sudah lenyap. Transaksi jual-beli yang klasiknya bertemu atau face to face serta melakukan perjalanan panjang menuju ruang-waktu (ranah), kini sudah tidak perlu terjadi lagi. Inilah yang disebut 'ekonomi digital atau digitalisasi ekonomi', yakni hubungan atau interaksi jual-beli yang diperantarai oleh perangkat-perangkat digital melampaui batasan ruang-waktu. Dengan kata lain, aplikasi Shopee ini adalah praksis dari konsep dromologi yang mengarah pada ontologi waktu (baca: waktu diorganisasikan) melalui kecepatan dan percepatan yang memunculkan pemadatan tempo kehidupan. Di dalam kehidupan eksistensial kontemporer, kecepatan berubah menjadi suatu kondisi keniscayaan yang tidak bisa di tolak. Sebagaimana yang dikatakan Virilio bahwa kehidupan kontemporer sangat "...menggantungkan diri pada kecepatan berlari; ia akan mati, bila terlalu lambat..." (Piliang, 2017: 56).

Lebih jauh, Shopee menggunakan strategi flash sale untuk menarik masyarakat atau konsumen sehingga singgah atau menggunakan 'dirinya' dalam hal bertransaksi untuk membeli keperluan kehidupan. Strategi yang barubaru ini dilakukan adalah Super Flash Sale Shopping Day 9.9 yang berlangsung dari tanggal 27 Agustus sampai 09 September 2018. Terkait fenomena ini, dalam dromologi Virilio adalah wujud pemadatan ruang-waktu, artinya didalam era informasi digital (narasi digital) telah menyebabkan semakin padat pula durasi 
waktu, serta semakin dekat pula jarak antara satu perbedaan dengan perbedaan berikutnya (Virilio dalam Piliang, 2017: 58). Dunia kini dikuasai oleh kekuasaangerak (moving-power), di mana segala sesuatu (benda, komoditas, bentuk, gaya , citra, dan tanda) dikondisikan untuk selalu bergerak dan mengalir seperti arus yang tak pernah diam. Wujud nyata dari ramalan Alvin Toffler, bahwa abad 21 merupakan abad informasi, di mana terjadi dunia lalu-lintas informasi (Hadi, 2005: viii).

Bertolak dari pendapat Virilio tentang dromologi, dalam melihat atau terkait fenomena Super Flash Sale Shopping Day ini, dari jangka waktunya saja menggambarkan suatu praksis kecepatan dan percepatan yang memang melekat pada manusia kontemporer di dalam kehidupannya. Cara kerjanya dengan kecepatan dan percepatan produksi serta konsumsi, yakni durasi Super Flash Sale Shopping Day yang diberikan pada batas tempo tertentu, yang sejatinya jika dicermati secara mendalam hanyalah suatu tipuan dalam ruang kapitalisme, yang cepat dalam siklus kehampaan.

Dalam memasarkan promo tersebut, Shopee menggunakan realitas strategis, kekuasaan pengetahuan, dan kekuasaan pergerakan lewat kemajuan teknologi. Realitas strategis dalam pra dan proses pemasaran promo tersebut, seperti menampilkan di Instagram story ${ }^{1}$ secara kejutan, Youtube, menggunakan jaringan aktor, dan lain sebagainya. Antara lain, seperti berikut ini (lihat Gambar 4).

Gambar di atas merupakan tampilan iklan Super Flash Sale Shopping Day yang muncul di laman youtube.

Sebuah fitur yang memungkinkan pengguna mengirim foto dan video dan akan menghilang setelah 24 jam.
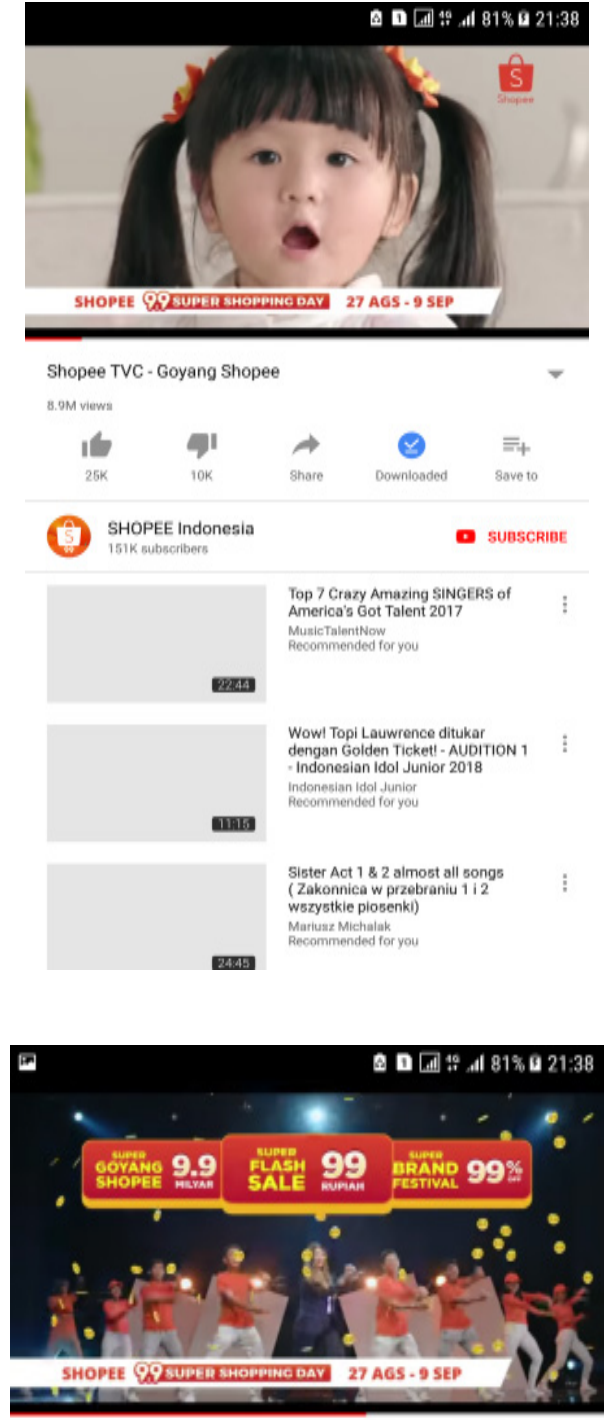

Shopee TVC - Goyang Shopee

8.9.9 พหwa

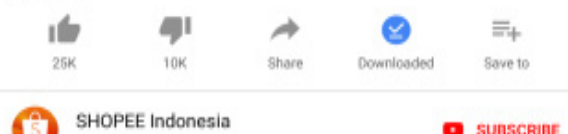

1514 nherecthern

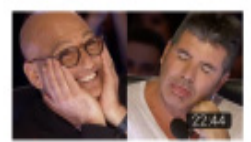

Top 7 Crazy Amazing SINGERS o America's Got Talent 2017 MusicTilantinow

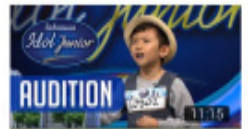

Wowt Topi Lauwrence ditukar dengan Golden Tickett-AUDIT
- Indonesian Idol Junior 2018. Indonemian idol Juniar
frecommended for you

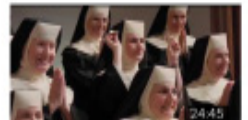

Sister Act 1 \& 2 almost all sonps w prebraniu $1 \mathrm{i} 2$ wozystic posenki) Martust Michalak

Sumber: Tangkap layar ribadi dari laman Youtube.

Gambar 4. Iklan flash sale shopee 9.9 
Iklan ini akan muncul secara otomatis sebelum video yang kita pilih untuk ditonton di Youtube, dan secara terpaksa kita harus 'tamasya' melihat promo video dari Shopee ini karena tidak bisa di 'lewati'. Dengan kata lain, teknik framing fenomena pergerakan ini bisa dikatakan sebagai pemerkosaan visual pada masyarakat, yakni kita disuguhkan sesuatu yang tidak kita inginkan dan kita dipaksa untuk melihatnya. Suatu fenomena fantasmagoria yang mengelilingi kehidupan sosial dan sarat akan memunculkan kepanikan dan sarat histeria. Selain itu, pergerakan sosial dan lalu lintas teknologi dan komunikasi abad ke-21 yang tergambarkan sekilas dalam 'pemerkosaan visual' di atas, merupakan pergerakan dan lalu lintas phantom $^{2}$, yang mengarah pada histeria kapitalisme dalam konteks monopoli pasar, akumulasi ketegangan, dan akumulasi nilai surplus dan kapital serta maksimum keuntungan (Piliang, 2009: 129).

Lebih jauh, terkait dengan dromologi, kecepatan dan percepatan dari realitas strategis ini adalah kondisi piknolepsi. Piknolepsi adalah kondisi pemadatan dan tumpang tindih waktu. Dengan kata lain, berkaitan dengan frekuensi atau tingkat keseringan - semakin tinggi kecepatan dalam persepsi, semakin banyak dan sering kita melihat benda-benda atau iklan, dan semakin tinggi pula diferensiasi di antara benda-benda itu (Piliang, 2017: 61). Kondisi yang ada dalam piknolepsi adalah kepusingan atau kemabukan, yang terjadi karena penumpukan dan tingginya frekuensi kemunculan citra -

Sesuatu yang bisa ditangkap atau diraih oleh indera, namun tidak memiliki substansi. kombinasi ketakterdugaan dan kejutankejutan. Hal ini pun terepresentasikan dalam fenomena proses strategi Shopee untuk memasarkan promo Super Flash Sale Shopping Day-nya.

Selain itu, akibat keseketikaan, ketakterdugaan, dan kejutan-kejutan serta kecepatan dan percepatan dari fenomena promo Super Flash Sale Shopping Day Shopee ini, melahirkan ekstasi pada diri manusia. Kondisi ekstasi yang dimaksud adalah kondisi larutnya manusia di dalam kecepatan dan percepatan perubahan (Gleick, dalam Piliang, 2017: 57). Kondisi ekstasi adalah sebagai fenomena kebebasan dan pemenjaraan. Artinya, kecepatan membebaskan manusia dari berbagai hambatan, khususnya hambatan ruangwaktu dan memungkinkan manusia untuk menjalankan model kehidupan yang instanisasi. Kondisi tersebut sekaligus memerangkap manusia dalam arus suatu bentuk ketergantungan, candu atau keniscayaan.

Sementara itu, promo yang berlari ini juga melahirkan patologi psikis pada konsumen atau masyarakat, yakni kondisi panik, yaitu kondisi mental yang ditandai oleh ketakutan tanpa alasan yang menyebabkan manusia berlari atau melakukan tindakan cepat, yang sering tanpa arah. Dalam wacana kapitalisme, pascamodernisme, dan cyberspace, panik adalah kondisi yang lumrah, yang menghasilkan mentalitas ekstasi, yakni mentalitas yang merayakan kegairahan dan puncak kecepatan, sehingga melupakan mereka akan arah tujuan (Piliang, 2017: 42). Dalam hal ini adalah panik informasi dan panik konsumsi. Sederhananya, representasi dari terminologi ini dikaitkan dengan promo 
Shopee adalah 1) tingkat intensitas kemunculan iklan promo ini tanpa disadari atau tidak, akan memengaruhi kondisi psikis dari masyarakat yang melihatnya, 2) terjadi panik informasi, yakni ketika informasi mendatangi konsumen atau masyarakat sebagai bom informasi tanpa mereka mampu mengambil manfaat dari semuanya, yang diistilahkan Baudrillard sebagai implosi (peleburan segala batas), yakni semacam kondisi ekspansi informasi ke dalam manusia - ledakan ke dalam, 3) panik konsumsi merupakan kondisi ketika konsumsi berlangsung, tanpa konsumen atau masyarakat paham logikanya - era baru budaya konsumen, komersialisasi segala sisi kehidupan dengan segala muatan kesemuanya (Chaney, 2017: 58).

Proses promo iklan ini yang masuk ke beragam media merupakan cerminan 'industrialisasi tatapan' dalam dromologi. Intervensi dari promo iklan ini terhadap pandangan dan tatapan konsumen atau manusia telah terindustrialisasi lewat media layar. Layar diubah menjadi ranah medan perang para pegiat di bisnis online shop, termasuk Shopee. Kini, mereka membawa perang ke arah perang layar, tidak lagi di atas tanah, tapi di atas permukaan layar. Layar yang awalnya sebagai media perluasan dalam pandangan, kini menjelma memperluas atau mempertajam 'kekuasaan pandangan tanpa ada yang luput dari pengawasan' (Piliang, 2017: 72). Dengan kata lain, suatu praksis lain dari konsep panoptikon yang dicetuskan oleh Foucault dalam era literasi digital dan atau literasi media (Lechte, 2001:179-181). Artinya, semua tatapan masyarakat atau konsumen dalam pengawasan Shopee, sehingga mereka menampilkan promo tersebut pada setiap layar mobile para konsumen atau masyarakat. Inilah yang disebut sebagai industrialisasi tatapan.

Selain menggunakan ranah kemajuan teknologi, informasi, dan perang layar, Shopee juga menggunakan manusia sebagai pendukung dalam promo flash sale ini. Istilah dalam sosiologi ekonomi untuk hal ini adalah jaringan sosial. Jaringan sosial adalah hubungan antarindividu yang memiliki makna subyektif yang berhubungan atau dikaitkan dengan sesuatu sebagai simpul dan ikatan (Damsar dan Indrayani, 2015: 158), tidak menutup kemungkinan hubungan tersebut hanya sebatas rasio instrumental belaka. Jaringan sosial dalam promo Super Flash Sale Shopping Day ini adalah jaringan mikro, yakni bentuk jaringan yang selalu ditemukan dalam kehidupan sehari-hari, artinya suatu interaksi sosial atau hubungan sosial antarindividu yang akhirnya melahirkan jaringan sosial (Salim, 2008: 6-9; Damsar dan Indrayani, 2015: 160; Usman, 2015: 56-57).

Dalam penelitian ini, promo flash sale Shopee menggunakan salah satu akun selebgram yang dewasa ini sedang terkenal dan menjadi perbincangan netizen di Indonesia, yakni Raden Rauf atau nama terkenalnya Om Rauf atau Auf. Dengan utilitarian pamornya tersebut, yang digunakan sebagai pelicin, sebagai jembatan, dan sebagai perekat. Misalnya, sebagai pelicin, artinya bahwa lewat akun selebgram Raden Rauf, Shopee memberikan eksesekses langka yang dilakukannya dengan jaminan suatu kepastian, lewat promo yang dilakukan oleh selebgram Raden Rauf. Di sisi lain, ada kompleksitas keuntungan di dalamnya, praksis dari 
"kapitalisme informasi" (Djaya, 2012: 73-74). Keuntungan bagi pembeli, yakni kepastian dan ketepatan informasi suatu harga barang, promo lain yang tersedia, diskon, dan lain sebagainya. Sedangkan keuntungan di pihak pedagang (Shopee) dan yang mengiklankan (selebgram), memperoleh laba dan menambah follower (pengikut) merupakan konsekuensi logis dari keadaan yang terjadi. Sebelumnya, Jaringan sosial mikro mempunyai tiga fungsi dalam praksisnya, yakni sebagai pelicin, sebagai jembatan, dan sebagai perekat (Damsar dan Indrayani, 2015: 161).

Lebih jauh, terkait dengan dromologi adalah terjadinya persilangan rizomatik antara ekonomi dan kapital yang menghasilkan komodifikasi dan komersialisasi seseorang (lihat Gambar 5). Sebagaimana yang dikatakan Virilio (dalam Piliang, 2017:39), hal ini dilakukan kapitalisme untuk menyelamatkan wajah komitmen 'kecepatan, artinya meningkatkan perputaran dan pergantian gaya, citra, dan produk (penggunaan selebgram), sehingga ia (baca: kapitalisme) membentuk komersialisai segala sisi kehidupan dengan segala muatan kesemuanya, juga secara langsung ataupun tidak telah mendoktrin pikiran. Kecepatan komodifikasi ini atau sebut saja megastrategi, tak lain dengan maksud perputaran uang demi motif keuntungan saja. Trik-trik simulasi media dan industri, seperti yang dilakukan Shopee, merupakan gambaran dari dromonomics ${ }^{3}$.

Di satu sisi, fenomena terkait merupakan praktik dari tubuh sebagai repertoire komoditi, walaupun yang

\footnotetext{
Waktu, ruang, uang, dan kecepatan merupakan unsur yang tidak bisa dilepaskan dari wacana kapitalisme yang membentuk model ekonomi berbasis kecepatan.
}
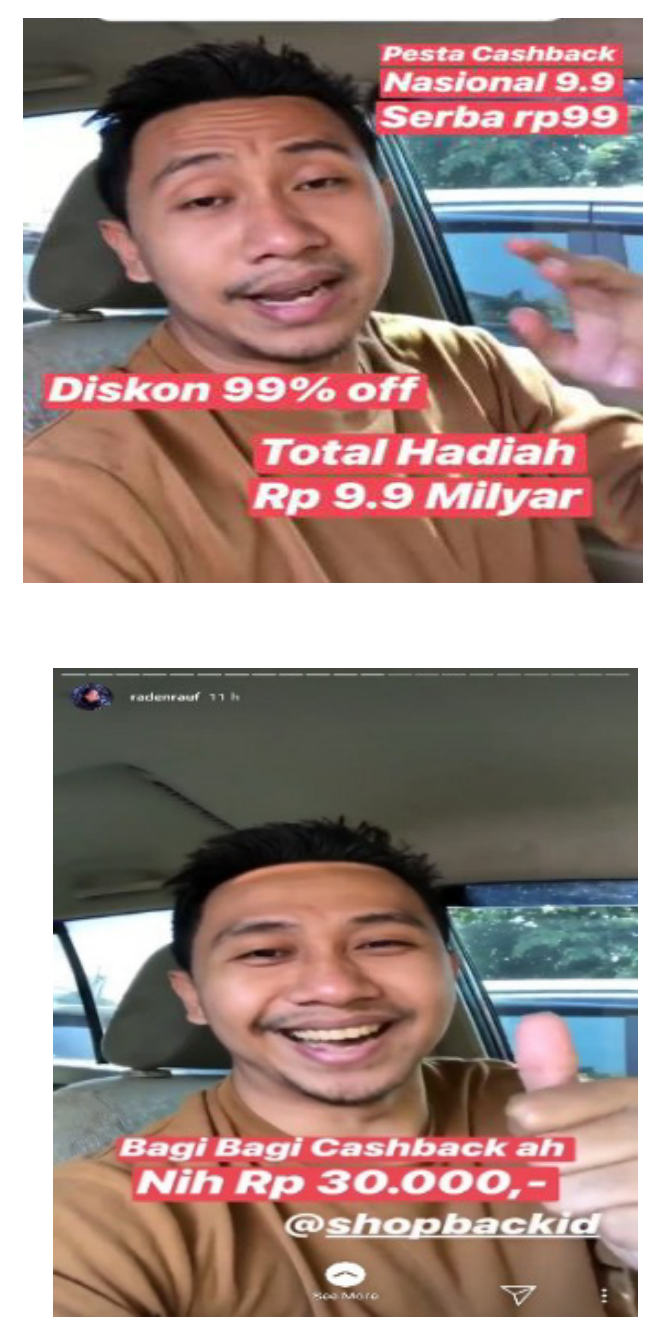

(Sumber: Akun instagram Raden Rauf)

Gambar 8. Promote iklan Flash Sale dari Shopee oleh akun selebgram (@radenrauf) di Instagram.

dilakukannya merupakan artifisial bukan tubuh realitas. Di dalam hipermarket atau marketplace, tubuh yang menjadi ikon dihabiskan nilai gunanya, semata untuk memperoleh keuntungan yang maksimum (Nava, 1992: 67). Fenomena terkait dalam media (instagram) merupakan penandaan pengonsumsian budaya populer dengan penggunaan bintang (seseorang yang menjadi panutan) yang mempropagandakan 
sebagai ikon kultural (Atmadja dan Ariyani, 2018: 165).

\subsection{Promo 9.9 : Flash Sale 24 kali Sehari}

Kegiatan ekonomi dalam hal ini transaksi pembelian barang oleh konsumen di marketplace Shopee tidak hanya ditentukan oleh dorongan memenuhi kebutuhan sehari-hari. Lebih dari itu, kehadiran promo 9.9 Shopee dengan beragam promo mulai dari harga Rp. 99, voucher, gratis ongkos kirim, cashback, dan sebagainya seakan membius tindakan konsumen untuk berlombalomba memenuhi "hasrat" keinginan yang hanya bisa didapatkan pada waktu tertentu di hari itu dengan kecepatan "klik". Kecepatan membuat manusia untuk terusbergerak atau memaksauntuk tidak diam, meskipun proses ekonomi terus berjalan. Salah satu trik pada kapitalisme lanjut, yang menciptakan leisure class, hingga menciptakan atau memanenkan masyarakat konsumsi atau konsumerisme sebagai gaya hidup, terlebih gaya hidup dunia maya menjadi bagian dari subkultur, mungkin nanti akan menjelma menjadi kultur, masyarakat modern.

Dalam penelitian ini, mengapa terjadinya percepatan revolusioner (dari face to face ke marketplace) bisa di lihat dari fenomena dalam dromologi seperti berikut:

1. Pelipatan ruang-waktu (time space compression), melipat waktu artinya memperpendek jarak waktu dengan meningkatkan kecepatan (velocity) atau memperpendek durasi.

2. Pemadatan

waktu-tindakan (timeaction condensation) kurang lebih artinya pemadatan berbagai tindakan ke dalam masa atau satuan waktu yang berjenjang seperti hari, jam, menit hingga detik.

3. Miniaturisasi ruang-waktu (timespace miniaturisation), bisa diartikan sebagai meminiaturkan atau mengecilkan ruang maupun waktu.

4. Pemadatan ruang-waktu simbolik (symbolic time-space compression) yaitu peringkasan dalam sebuah simbol.

5. Peringkasan ruang-waktu psikis (psychal time-space condensation) pelipatan dan peringkasan keempat hal diatas akibat kemajuan dari teknologi telekomunikasi maka pandangan orang terhadap ruang dan waktu menjadi semu.

Kehadiran marketplace cepat atau lambat akan mengubah cara orang dalam membeli kebutuhan hidup dengan cukup hanya mengandalkan gawai saja. Artinya, akan lahir budaya instan, di mana orang tak perlu pergi ke pasar tradisional maupun modern secara beramai-ramai. Setiap orang pada akhirnya akan dengan mudah memenuhi kebutuhan tanpa harus mengantri dan berdesakan dengan konsumen yang lain. Penanaman dari doktrin posmodern, yakni menembus tapal batas realitas (O'Donnell, 2009: 116).

\section{SIMPULAN}

Shopee sebagai salah satu marketplace memungkinkan dan memudahkan proses jual-beli antar penjual-pembeli yang jaraknya terpisah oleh garis horizon (jauh). Lewat aplikasi ini, jarak, ruang, dan waktu sudah lenyap. Transaksi jual-beli yang klasiknya bertemu atau face to face serta melakukan perjalanan 
panjang menuju ruang dan waktu atau ranah, kini sudah tidak perlu terjadi lagi. Dengan kata lain, semuanya bergerak dalam genggaman kita, suatu efek dari new media yang tidak mungkin untuk dihindarkan. Dalam pengertian inilah medium media terkait disebut oleh Virilio sebagai 'bola mata raksasa' atau disebut Baudrillard sebagai realitas kedua. Lebih jauh, berdasarkan analisis di atas, diperoleh pemahaman bahwasanya Shopee menggunakan realitas strategis, kekuasaan pengetahuan, dan kekuasaan pergerakan lewat kemajuan teknologi. Realitas strategis dalam pra dan proses pemasaran promo tersebut, seperti menampilkan di Instagram Story dan Youtube secara kejutan, menggunakan jaringan aktor, yaitu bintang sebagai ikon kultural dengan menggunakan semua nilai gunanya, meskipun dalam artifisial, juga industrialisasi tatapan. Marketplace dengan berbagai strategi penjualan yang dipilih, seperti flash sale telah melahirkan budaya instan atau instanisasi hasil dari percepatan budaya, orang tidak lagi di batasi oleh ruang-ruang, tetapi oleh waktu.

Perihal di atas, memainkan 'hasrat' yang akan melahirkan 'histeriahisteria kapitalisme'. Sederhananya, menanamkan lebih dalam lagi ideologi konsumerisme pada masyarakat. Keyakinan ideologi ini akan menggiring pada kefanatikan yang membuat terjebak pada pemberhalaan budaya konsumen. Segala sesuatu kini tampil dalam bentuk representasinya, dan di dalam dunia yang di dominasi oleh ontologi citra, di mana hanya representasi itu yang dianggap sebagai nyata (real). Berkenaan dengan hal terkait, kiranya permasalahan ini diperlukan suatu kajian bersama, supaya yang artifisial dan nyata tetap saling berkontribusi dalam hal perekonomian, misalnya. Manusia harus sadar sehingga tidak terlena dengan cyberspace yang semakin meninabobokan dengan keniscayaannya.

\section{DAFTAR PUSTAKA}

APJII. 2017. Infografis Penetrasi dan Perilaku Pengguna Internet di Indonesia Survey 2017. Asosiasi Penyelenggara Jasa Internet Indonesia. Diperoleh dari (http://www.apjii.or.id/v2/read/ content/info-terkini/301/penggunainternet-ind onesia-tahun2014sebanyak-88.html.)

Ariyani, Nur Indah, dan Okta Hadi Nurcahyono. 2014. Digitalisasi Pasar Tradisional: Perspektif Teori Perubahan Sosial. Jurnal Analisa Sosiologi, 2 (1): 1-12.

Atmadja, Nengah Bawa, dan Luh Putu Sri Ariyani. 2018. Sosiologi Media: Perspektif Teori Kritis. Depok: PT. Rajagrafindo Persada.

Benaziria. 2018. Pengembangkan Literasi Digital pada Warga Negara Muda dalam Pembelajaran PPKn Melalui Model VCT. Jurnal Pendidikan IlmuIlmu Sosial, 10 (1), 11-20.

Bungin, Burhan. 2014. Sosiologi Komunikasi: Teori, Paradigma, dan Diskursus Teknologi Komunikasi di Masyarakat. Jakarta: Kencana.

Chaney, David. 2017. Life Styles: Sebuah Pengantar Komprehensif. Yogyakarta: Jalasutra.

Damsar dan Indrayani. 2015. Pengantar Sosiologi Ekonomi. Jakarta: PrenadaMedia Group.

Dewi, Noviyanti Kartika, dan Dian Ratnaningtyas Affifah. 2019. Analisis Perilaku Cyberbullying Ditinjau dari Kemampuan Literasi Sosial Media. Journal Empathy Conus, 1 (1), 60-68. 
Djaya, Ashad Kusuma. 2012. Teori-Teori Modernitas dan Globalisasi: Melihat Modernitas Cair, Neoliberalisme, serta Berbagai Bentuk Modernitas Mutakhir. Bantul: Kreasi Wacana.

Emarketer. 2018. Global Digital Users 2018. Diperoleh dari

https://www.emarketer.com/content/ global-digital-users-2018.)

Emiri. 2015. Digital Literacy Skills Among Librarians In University Libraries In The 21st Century In Edo And Delta States, Nigeria. International Journal Of Scientific \& Technology Research, 4 (08), 153-159.

Furchan, Arief, dan Agus Maimun. 2005. Studi Tokoh Metode Penelitian Mengenai Tokoh. Yogyakarta: Pustaka Pelajar.

Gilster. 1997. Digital Literacy. New York: Wiley.

Hadi, Astar. 2005. Matinya Dunia Cyberspace: Kritik Humanis Mark Slouka Terhadap Jagat Maya. Yogyakarta: LKiS.

iPrice. 2018. Data Waktu yang dihabiskan Konsumen Indonesia Saat Mengunjungi Toko Online. Diperoleh dari (https:// iprice.co.id/trend/insights/risetdan-data-waktu-yang-dihabiskankonsumen-ind on esia - sa a t mengunjungi-toko-online/)

Jeko, I. R. 2015. Shopee, Aplikasi Belanja Online C2C Meluncur di Indonesia. Diperoleh dari (https://www. liputan6.com/ tekno/read/2379136/ Shopee-aplikasi-belanja-online-c2cmeluncur-di-indonesia.)

Julianto, Pramdia Arhando. 2017. Perusahaan Ritel Banyak Tutup, Apa Yang Sebenarnya Terjadi?. Diperoleh dari (https://ekonomi.kompas. $\mathrm{com} / \mathrm{read} / 2017 / 10 / 27 / 184542026 /$ perusahaan-ritel-banyak-tutup-apayang-sebenarnya-terjadi)

Knox, J. 2014. Digital culture clash: "massive" education in the E-learning and Digital Cultures MOOC. Distance Education, 35(2), 164-177.
Lechte, John. 2001. 50 Filsuf Kontemporer: dari Strukturalisme sampai Postmodernitas. Yogyakarta: PT. Kanisius.

Listiyani, Dini. 2017. WOW! 50 Juta Orang Indonesia Senang Belanja Online. Diperoleh dari (https://techno.okezone.com/ $\mathrm{read} / 2017 / 08 / 10 / 207 / 1753147 / \mathrm{wow}-$ 50-juta-orang-ind onesia-senangbelanja-online.)

Nava, Mica. 1992. Consumerism and Its Contradiction. London: Sage Publication.

Nugroho, Rento Ari. 2016. Shopee Gratiskan Ongkos Kirim ke Seluruh Indonesia. Diperolah dari (http://jogja. tribunnews.com/2016/02/06/Shopeegratiskan-ongkos-kirim-ke-seluruhindonesia.)

O’Donnell, Kevin. 2009. Postmodernisme. Yogyakarta: PT. Kanisius.

Osborne, Richard, dan Borin Van Loon. (1998). Mengenal Sosiologi. Bandung: Mizan.

Pamungkas, Arde Candra, Akhmad Muawal Hasan, Nur Janti, Hesti Pratiwi Ambarwati, Taufik Nurhidayat, dan Prasetyo Wibowo. 2014. Online: Geliat Manusia dalam Semesta Maya. Yogyakarta: Ekspresi Buku.

2009. Posrealitas: Realitas Kebudayaan dalam Era Posmetafisika. Yogyakarta: Jalasutra.

Putri, Winda Destiana. 2015. Shopee, Aplikasi Belanja Pertama Berkonsep Konsumen ke Konsumen. Diperoleh dari (https://www.republika.co.id/ berita/gaya-hidup/trend/15/12/01/ nyoaf0359-Shopee-aplikasi-belanjapertama-berkonsep-konsumen-kekonsumen.)

Salim, Agus. 2008. Pengantar Sosiologi Mikro. Yogyakarta: Pustaka Pelajar.

Santosa, S. 2001. The Application of E-Commerce in Shipping Warehousing Industri. Jurnal 
Akuntansi \& Keuangan, 3(2), 126-141. Yanti, Mery, dan Yusnaini. 2018. Setyani. 2017. 5 Toko Ritel yang Bangkrut Tergerus Toko Online. Diperoleh dari (https://www.rappler.com/ indonesia/berita/ 186707-5-toko-ritelbangkrut-tergerus-toko-online)

Usman, Sunyoto. 2015. Sosiologi: Sejarah, Teori, dan Metodologi. Yogyakarta: Pustaka Pelajar.

Virilio, P. 1991. The Aesthetics of Disappearance., trans. M. Polizzotti, New York: Semiotext(e). The Narration of Digital Literacy Movement in Indonesia. Jurnal Informasi: Kajian Ilmu Komunikasi, 48 (2), 243-255.

Yolania, Nikita. 2016. Shopee, Aplikasi Online Shopping Multinasional Berbasis Mobil Application. Diperoleh dari (http://careernews.id/event/ view/4085-Shopee-Aplikasi-OnlineShopping-Multinasional-BerbasisMobile-Application 